\title{
Dischissus japonicus Andrewes (Coleoptera: Carabidae), New to Korea
}

\author{
Park Jong Kyun* and Jinyoung Park
}

Department of Applied Biology, College of Ecology and Environmental Science, Kyungpook National University, Sangju 742-711, Korea

\section{한국산 Dischissus 속 1 미기록종 보교}

\author{
박종균 ${ }^{*}$. 박진영
}

경북대학교 생태환경대학 생물응용학과

ABSTRACT: Dischissus japonicus Andrewes is reported firstly in Korea. Diagnosis and photograph of adult are provided.

Key words: Taxonomy, New record, Dischissus japonicus, Coleoptera, Korea

초 록: 먼지벌레류 중에서 Dischissus japonicus (신칭: 작은털보먼지벌레)를 국내 첫 보고하며, 특이사항과 성충사진을 제공하고자 한다.

검색어: 분류, 작은털보먼지벌레, 딱정벌레목, 한국

Nine species of the genus Dischissus were reported from the Palaearctic region (Baehr, 2003) and most species are distributed in China and Japan. Among them, Dischissus mirandus Bates, 1873 was the only species reported in Korea up to now (ESK and KSAE, 1994; Park and Paik, 2001).

Genus Dischissus is easily distinguished by dense setae of whole body, globular shape and deep punctuation of pronotum and two pairs of yellowish or yellow-reddish large spot of elytra.

\section{Key to species of the genus Dischissu from Korea}

1. Body length more than $17 \mathrm{~mm}$; pronotum without yellowish lateral border line at each lateral margin; legs blackish ..

D. mirandus

- Body length less than $10 \mathrm{~mm}$; pronotum with yellowish lateral border line at each lateral margin; legs yellowish ..

D. japonicus

*Comesponding author: entopark@knu.ac.kr

Received October 17 2012; Revised January 172013

Accepted January 282013
Subfamily Panagaeinae Bonelli, 1810

Tribe Panagaeini Bonelli, 1810

Genus Dischissus Bates, 1873

\section{Dischissus japonicus Andrewes, 1933 (신칭:} 작은털보먼지벌레)

(Fig. 1)

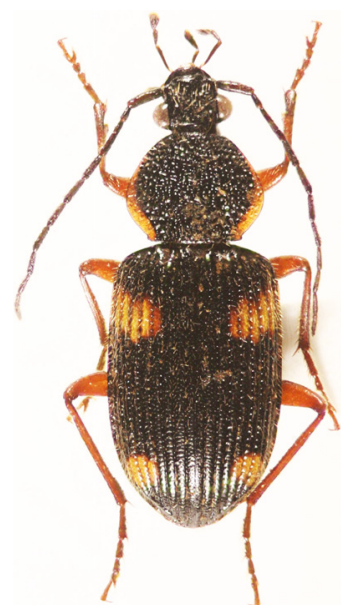

Fig. 1. Adult habitus of Dischissus japonicus from Korea. 


\section{Diagnosis}

Body length 8-9 mm. Head, pronotum, elytra and ventral part black color, mendibles, palpi and antennae dark brown, legs yellowish or reddish brown. Head with irregularly strong punctures; length longer than width. Pronotum with yellowish lateral border lines from about $1 / 4$ area of pronotum to basal angle narrowing to anterior part; basal angle with small teeth. Elytral striae deep; elytral intervals wide and convex, with yellowish spots at anterior and posterior area; anterior spots more large than posterior spots.

Matenial examined: 1 \&, 22, VI, 2001, Mt. Jirisan, Gyeongsangnam-do, Korea Coll. S. L. An

Notes: This species can be easily identified by dense setae, yellowish border of pronotum and large band pattern on elytra. Numbers of the genus Dischissus were known to well fly and usually live on the tree in forest area.

Distribution: Korea (new record), China, Japan.

\section{Acknowledgements}

We really thanks to Dr, Seung-Lak An (National Science
Museum, Daejeon) for the loan of the valuable specimen. This study was supported by the project of the survey of Korean indigenous species of the National Institute of Biology Resources (NIBR) under the Ministry of Environment, Korea.

\section{Literature Cited}

Andrewes, H.E., 1933. On the types of Oriental Carabidae described by V. de Motschulsky. (Part II). Trans. R. Entpmol. Soc. Lond. 81, 1-19.

Baehr, M., 2003. Panagaeini, p 447. In: I. Lobl \& A. Smetana (editors); Catalogue of Palaearctic Coleoptera. Vol 1. Stenstrup: Apollo Books, pp. 819

Bates, H.W., 1873. On the geodephagous Coleoptera of Japan. Trans. R. Entpmol. Soc. Lond. 21, 219-322.

Bonelli, F.A., 1810. Observation entomologiques. Premiere partie (cicindeletes et portion des carabiques) [with the " Tabula synoptica exhibens genera carabicorum in sectiones et stripes disposita"]. Turin, pp. 58

ESK, KSAE, 1994. Check list of Insects from Korea. The Entomological Society of Korea and Korean Society of Applied Entomology. Kon-kuk Univ. press, Korea, pp. 130.

Park, J.K., Paik, J.C., 2001. "Family Carabidae. Economic Insecta of Korea 12” In: Insecta koreana. National Institute of Agricultural Science and Technology, Suwoon Suppl. 19, pp. 170. 